\title{
The ecology of environmental DNA and implications for conservation genetics
}

\author{
Matthew A. Barnes ${ }^{1}$ (1) $\cdot$ Cameron R. Turner $^{2,3} \mathbb{C}_{\mathbb{C}}$
}

Received: 6 April 2015/Accepted: 31 August 2015/Published online: 8 September 2015

(C) The Author(s) 2015. This article is published with open access at Springerlink.com

\begin{abstract}
Environmental DNA (eDNA) refers to the genetic material that can be extracted from bulk environmental samples such as soil, water, and even air. The rapidly expanding study of eDNA has generated unprecedented ability to detect species and conduct genetic analyses for conservation, management, and research, particularly in scenarios where collection of whole organisms is impractical or impossible. While the number of studies demonstrating successful eDNA detection has increased rapidly in recent years, less research has explored the "ecology" of eDNA-myriad interactions between extraorganismal genetic material and its environment-and its influence on eDNA detection, quantification, analysis, and application to conservation and research. Here, we outline a framework for understanding the ecology of eDNA, including the origin, state, transport, and fate of extraorganismal genetic material. Using this framework, we review and synthesize the findings of eDNA studies from diverse environments, taxa, and fields of study to highlight important concepts and knowledge gaps in eDNA study and application. Additionally, we identify frontiers of conservation-focused eDNA application where we see the most potential for growth, including the use of eDNA for estimating population size, population genetic and genomic
\end{abstract}

Matthew A. Barnes

matthew.a.barnes@ttu.edu

Cameron R. Turner

crt343@ecosysgen.com

1 Department of Natural Resources Management, Texas Tech University, Lubbock, TX 79409, USA

2 Department of Biological Sciences, University of Notre Dame, Notre Dame, IN 46556, USA

3 ecoSystem Genetics LLC, South Bend, IN 46635, USA analyses via eDNA, inclusion of other indicator biomolecules such as environmental RNA or proteins, automated sample collection and analysis, and consideration of an expanded array of creative environmental samples. We discuss how a more complete understanding of the ecology of eDNA is integral to advancing these frontiers and maximizing the potential of future eDNA applications in conservation and research.

Keywords Environmental DNA · Metabarcoding · Metagenetics - Metagenomics - Monitoring - Surveillance

\section{Introduction}

Conservation and ecological understanding have benefitted from recent, rapid advancements in non-invasive genetics, the analysis of genetic material within traces of organisms such as hair, feces, and other shed biological materials, rather than whole organisms (Beja-Pereira et al. 2009). One developing advancement in non-invasive genetic methods is the study of environmental DNA (eDNA), which refers specifically to the analysis of genetic material collected not through targeted methods such as deploying fur traps or collecting fresh scats, but extracted from bulk environmental samples such as soil, water, or air (Taberlet et al. 2012). Rapid advances in technology and concurrent declines in cost have landed eDNA on a recent annual survey of global conservation horizons (Sutherland et al. 2013) while others herald a future of "conservation in a cup of water" (Lodge et al. 2012). While the first analyses of genetic material from environmental samples-and indeed, the first use of the term environmental DNAoccurred within the field of microbiology, where researchers extracted DNA directly from marine sediments 
to characterize the microbial communities contained within (Ogram et al. 1987), more recently, similar methods have been applied as a tool for the study and conservation of macrobial communities. Over time, many creative methods have been developed for the "sight-unseen" detection of organisms (sensu Jerde et al. 2011). Today, diverse fields of biological and environmental study use DNA to detect various taxa across many different types of environments, including forensics (van Oorschot et al. 2010), fecal pollution tracking (Caldwell et al. 2011), paleogenetics (Pedersen et al. 2015), and environmental biosafety (Nielsen et al. 2007). Detection and analysis of eDNA have been the topic of several recent literature reviews (Blanchet 2012; Díaz-Ferguson and Moyer 2014; Rees et al. 2014b; Bohmann et al. 2014), including one focused on the conservation biology implications of eDNA (Thomsen and Willerslev 2015). However, the present review uniquely examines the conservation applications of eDNA through a lens we call "the ecology of eDNA."

The ecology of eDNA includes its origin, state, transport, and fate within the environment. Understanding the origin of eDNA- the source of an organism's genetic material shed into its environment and the factors influencing its production- can inform our understanding about the taxa and environments for which eDNA represents an effective conservation and research tool. Understanding the state of eDNA — characterizing the mutable forms of eDNA after it is shed from an organism and as it moves through the environment-provides insight into its capture and analysis. eDNA is transported through the environment after it is shed from an organism, and understanding this transport is essential for relating detected eDNA to species presence in space and time. Finally, understanding the fate of eDNA-how it degrades and what factors influence degradation-also improves spatiotemporal inferences of species presence from eDNA. To illustrate this framework, we review key findings of eDNA studies from diverse environments, taxa, and fields. An exhaustive review of the ever-increasing list of relevant literature pertaining to DNA detection of species is nearly impossible; however, we highlight cases across many fields that can inform conservation and study of extant macrobiota. We intentionally exclude intraorganismal eDNA (e.g., microbial eDNA) from our scope because its ecology is not different from that of the organisms themselves. In contrast, we argue that extraorganismal eDNA interacts with its environment in unique ways that matter for conservation applications.

Following our development of the ecology of eDNA framework, our review concludes with frontiers of conservation-focused eDNA applications in which we see the most potential for growth, including the use of eDNA for estimating population size, population genetic and genomic analyses via eDNA, inclusion of other indicator biomolecules such as environmental RNA or proteins, automated sample collection and analysis, and consideration of a wide array of creative environmental samples. A more complete understanding of the ecology of eDNA will contribute to the advancement of these frontiers and the maximization of additional future eDNA applications. Before exploring the ecology of eDNA in detail, we briefly review its previous conservation applications.

\section{A brief history of environmental DNA in conservation}

As a conservation tool, application of eDNA technology has focused primarily on the detection of target species, especially in cases where traditional sampling strategies may fall short. For example, early detection and rapid response represent cornerstones of effective management for invasive species (Lodge et al. 2006); however, despite the propensity of invasive populations to reach large population sizes with disruptive and obvious negative impacts, the initial propagules in an incipient invasion, as well as individuals at the leading edge of an invasion front, are rare and therefore difficult to detect. Thus, one of the first demonstrations of macrobial eDNA surveillance targeted invasive American bullfrogs (Rana catesbeiana) in French wetlands (Ficetola et al. 2008). The high-profile invasion of bigheaded carps Hypophthalmichthys molitrix and $H$. nobilis into waters of the midwestern United States (USA) has also represented a frequent target of eDNA surveillance efforts (Jerde et al. 2011; Mahon et al. 2013; Turner et al. 2014b). Other eDNA surveillance targets in natural waters have included Bluegill Sunfish (Lepomis macrochirus) invading ponds in Japan (Takahara and Minamoto 2013), New Zealand mudsnails (Potamopyrgus antipodarum) in streams of Idaho, USA (Goldberg et al. 2013), PontoCaspian zebra mussels (Dreissena polymorpha) in the midwestern USA (Egan et al. 2013), Louisiana crayfish (Procambarus clarkii) in France (Tréguier et al. 2014), and African Jewelfish (Hemichromis letourneuxi) and Burmese pythons (Python bivittatus) in Florida, USA's ponds (Moyer et al. 2014) and wetlands (Piaggio et al. 2014), respectively.

In addition to detecting invasive species in natural systems, conservation efforts have also been bolstered by the application of genetic surveillance methods to detect potential invaders in transit. For example, multiple studies have proposed the use of eDNA to detect invasive organisms within ballast waters of transoceanic ships ( $\mathrm{Li}$ et al. 2011; Mahon et al. 2012; Egan et al. 2013). Similar assays have successfully identified benthic invertebrates and their resting stages within ballast tank sediments (Darling and Tepolt 2008; Harvey et al. 2009; Briski et al. 2011). eDNA 
monitoring has also been proposed to assess authenticity of imported ornamental fish and identify potential invasive contaminant species within shipments (Collins et al. 2012) as well as within the trade of bait associated with recreational fishing (Mahon et al. 2014).

Threatened and endangered species have represented another common target for eDNA application because their rarity makes them difficult to observe and legal restrictions can limit even routine handling of such species through more traditional methods such as trapping (Thomsen et al. 2012a). For example, eDNA assays have been used to detect the eastern hellbender (Cryptobranchus a. alleganiensis), an amphibian of high conservation concern, in Indiana and Missouri, USA (Olson et al. 2012). In the UK, eDNA assays have been validated for detection of the threatened great crested newt Triturus cristatus (Rees et al. 2014a). Sigsgaard et al. (2015) reported that eDNA surveys for endangered fish in Denmark outperformed traditional methods. In the western USA, eDNA techniques have been optimized for detection of endangered Bull Trout Salvelinus confluentus (Wilcox et al. 2013, 2014), and other efforts have targeted rare marine mammals in the Baltic Sea (Foote et al. 2012).

Bioassessment, the characterization of ecosystem health through the measurement of local "indicator" organisms, is another conservation application which has benefitted from the integration of eDNA technology. For example, eDNA collected in terrestrial soil samples have been used to assess earthworm diversity which can relate to healthy ecosystem function (Bienert et al. 2012). Yoccoz et al. 2012 suggested that soil eDNA could also enable unprecedented rapid assessment of local plant communities and community-level responses to climate change. In terms of detection capabilities, the success of eDNA monitoring in aquatic environments has compared well with more traditional kick net sampling of benthic macroinvertebrates in Switzerland streams (Mächler et al. 2014). Furthermore, advancing technologies at decreasing costs hold the potential to make eDNA detection of a variety of indicator species (i.e. benthic invertebrates, fish, algae) faster and more cost effective than traditional surveys (Stein et al. 2014). We will provide additional examples as we proceed with the current review.

\section{Understanding the ecology of environmental DNA to improve conservation}

The rapid advancement of eDNA-based conservation applications and potential contributions to research are exciting; however, capturing and identifying eDNA as well as interpreting the results of these efforts will benefit from a more complete understanding of the ecology of eDNA (i.e. the origin, state, transport, and fate of eDNA molecules; Fig. 1). Research from many fields, including macrobial eDNA detection, microbiology, and water quality monitoring using fecal indicator bacteria, can all contribute to advancements in our understanding (Barnes et al. 2014). Below, we outline a framework consisting of four major questions to help guide research aimed at elucidating the ecology of eDNA.

\section{Origin: What are the physiological sources of eDNA production?}

Despite burgeoning interest and study of eDNA applications outlined above, the physiological origins of the material collected as eDNA remain uncertain (Fig. 1a). Microbial research that pioneered detection of genetic materials in environmental samples recognized that eDNA was present in both intracellular and extracellular forms (Ogram et al. 1987). It seems likely that multicellular organisms shed genetic material into their environment first as sloughed tissues and whole cells, and then those cells break down and release DNA into the environment. However, uncertainty remains in regards to the origins of sloughed materials. One of the earliest studies to target detection of vertebrate eDNA collected terrestrial mammal mitochondrial eDNA from aquatic environments, implicating fecal origins of such material (Martellini et al. 2005). Although feces remains a probable source of eDNA from a wide range of taxa targeted in aquatic (Thomsen et al. 2012a) and terrestrial environments (Andersen et al. 2012), high rates of success detecting taxa which produce slimy coatings such as amphibians (Ficetola et al. 2008) and fish (Jerde et al. 2011) suggest that other bodily fluids also act as a source of eDNA. Still other studies have demonstrated that dead carcasses and predator feces may also serve as an eDNA source in some cases (Merkes et al. 2014). Although some research has examined the size distribution of eDNA-bearing particles in aquatic environments to provide clues to its possible origins (Turner et al. 2014a), we are unaware of any microscopy-based examinations or other studies that directly address the question of what comprises eDNA collected for research and conservation.

Although the physical identity of the material comprising eDNA remains relatively unstudied, research efforts have demonstrated that many factors can influence the amount of genetic material released by organisms into their environments. For example, in an aquarium study of Idaho giant salamanders (Dicamptodon aterrimus), rate of eDNA production related positively to salamander biomass (Pilliod et al. 2014). A similar trend of eDNA production positively related to biomass was observed in Bluegill Sunfish (Maruyama et al. 2014). However, when corrected 


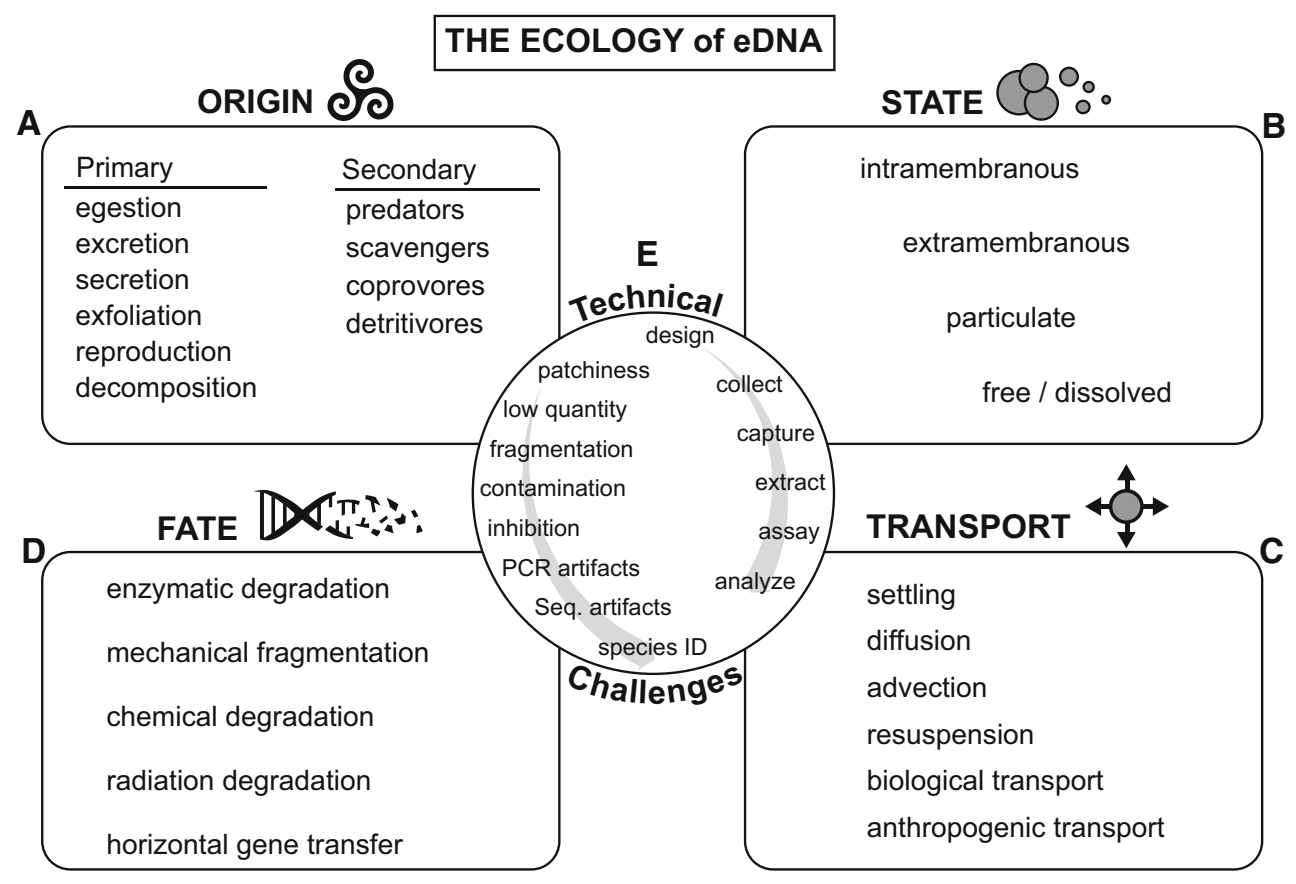

Fig. 1 Processes and properties within four domains of eDNA ecology (a-d) and key technical challenges (e) can guide eDNA conservation and research applications

for biomass, juvenile Bluegill Sunfish released eDNA at a higher rate than adults (target amplicon copies per hour per gram fish body weight), leading the authors to conclude that ontogenetic factors such as changes in behavior and metabolism influence eDNA production. Indeed, Klymus et al. (2014) found that increased feeding behavior of bigheaded carps increased eDNA shedding rates. Finally, beginning a trend that will emerge throughout our discussion of the major research questions facing future eDNA studies, local abiotic and biotic environmental conditions can influence eDNA production. For example, temperature and microbial activity contributed to DNA release from plant matter in freshwater sediments (Poté et al. 2009a).

Understanding the origin of eDNA - the source of the genetic material an organism sheds into its environment and what factors influence eDNA production- will inform our understanding about the taxa and environments for which eDNA will represent an effective conservation and research tool (Fig. 2a). For example, increased knowledge about the relationship between eDNA production and organism size, age, and/or biological activity can guide eDNA collection. Conservation efforts utilizing eDNA may be able to maximize success by taking into account temporal (e.g. seasonal events such as mating or die-offs) and spatial (e.g. diel or other cyclic migrations) patterns to target sampling windows in which genetic materials accumulate. On the other hand, relative differences between species or age classes within a species will help identify populations for which eDNA detection represents a sensitive and accurate detection tool and therefore useful for research and conservation.

\section{State: In what physical forms does eDNA exist?}

Related to the origin of eDNA is the question of its state within the environment (Fig. 1b). We previously noted that studies have found eDNA in the environment in both intracellular and extracellular forms. Presumably, eDNA transitions over time from intracellular to extracellular, and indeed considerable knowledge exists on the various ecological processes driving this transition (Levy-Booth et al. 2007). However, few studies have considered the state of what is collected during an eDNA survey. A notable exception is the work of Turner et al. (2014a) who looked at the particle size distribution of Common Carp eDNA in a small lake and zoo pond using serial filtration of water samples through filters of decreasing pore sizes $(180-0.2 \mu \mathrm{m})$ and concluding with an ethanol precipitation. They observed Common Carp eDNA across all size fractions, suggesting that Common Carp eDNA was collected as aggregations of cells on filters with larger pore sizes and extracellular DNA in the final precipitation (i.e. particle sizes $<0.2 \mu \mathrm{m}$ ). The largest percentage of total Common Carp eDNA recovered occurred within the 1-10 $\mu \mathrm{m}$ size fraction, but further size fractionation studies are needed to determine whether the findings of Turner et al. (2014a) represented a general trend across all eDNA studies or a taxa- or environment-specific phenomenon. 


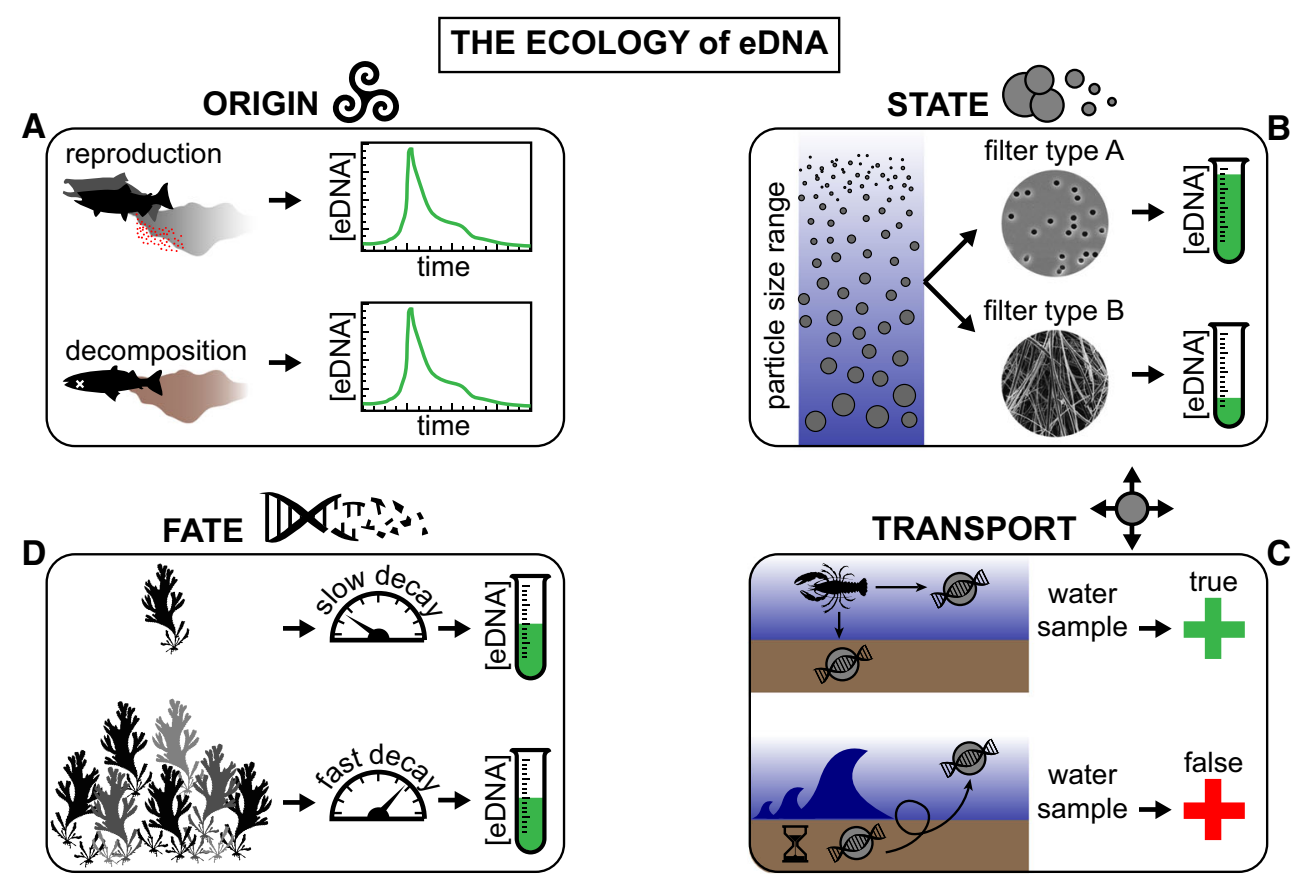

Fig. 2 eDNA ecology affects population inferences. a eDNA from reproduction and decomposition could produce similar temporal patterns despite different origins. b Different filter types could yield different eDNA concentrations that reflect particle size classes rather than

With an apparent lack of systematic comparison between eDNA capture methods to date (but see Deiner et al. 2015), trial and error or logistical constraints have dominated the field thus far (Turner et al. 2014a). Understanding the state of eDNA (i.e. characterizing the mutable forms of eDNA after it is shed from an organism and as it moves through the environment) will provide critical insight into its capture and analysis (Fig. 2b). For example, specific filter sizes or capture methods may be targeted to specific eDNA particles of interest based upon knowledge of the system under consideration. Furthermore, an improved understanding of the size distribution of not only target eDNA particles but also non-target eDNA and other particles responsible for PCR interference or inhibition could warrant use of multistage filtration or eDNA capture processes (e.g. "pre-filtration" of samples sensu Turner et al. 2014a). Knowledge of the size distribution of various particles in the aquatic environment will also inform navigation of the trade-off which exists between filter pore size and amount of water that can be processed before filter clog; smaller filter pore sizes capture more particles from the filtrate but limit filtration volume and speed while larger filter pore sizes filter larger volumes of water more quickly but may allow smaller target particles to pass through. A more thorough knowledge of the size distribution of target and non-target particles will permit selection of filter sizes and sampling strategies that optimally navigate sampling sensitivity and efficiency. The size of eDNA-bearing particles will also

population size differences. $\mathbf{c}$ Resuspension of old sedimentary eDNA could produce false inferences of presence after organisms are gone. d Different environmentally-mediated eDNA decay rates could confound inferences about population size or biomass from eDNA concentration

influence horizontal and vertical transport in the environment, aggregation and disaggregation dynamics, and consumption by other organisms (Turner et al. 2014a).

\section{Transport: How does eDNA physically move through the environment?}

After being shed from an organism, eDNA moves through its environment, which could influence the inferences of eDNA-based research and conservation (Fig. 1c). Much of the early work informing eDNA transport was inspired by concern over the transgenes of genetically modified organisms, especially agricultural crops, transferring to wild bacteria or other organisms. For example, Douville et al. (2007) sampled water to demonstrate that a gene from Bt corn could leach from the terrestrial into the aquatic environment and be transported many kilometers downstream. While the movement of plant material from an agricultural field into a nearby waterway is expected, a more surprising study in Switzerland found terrestrial plant eDNA in groundwater at a depth of $3.2 \mathrm{~m}$ and in groundwater-fed artesian fountains (Poté et al. 2009b). In a more direct study of the downstream transport potential of DNA, Foppen et al. (2011) generated synthetic DNA tracers for an injection experiment in two streams in the Netherlands. They observed that the physical movement of artificial DNA tracers matched the speed of standard $\mathrm{NaCl}$ tracers, but considerable reductions in DNA quantity with downstream 
movement suggested that adsorption, biological uptake, and other interactions between the DNA molecules and the stream environments were common. Even so, the artificial DNA tracer remained detectable at the furthest sampling site 1192 m downstream (Foppen et al. 2011).

As we've discussed, extracellular eDNA like the artificial tracer of Foppen et al. (2011) is just one component of what is detected in eDNA-based conservation and research applications. It is likely that eDNA represents a complex mixture of particles ranging from extracellular DNA molecules up to whole cells and aggregations of cells (Turner et al. 2014a). More recently, studies have begun to examine how this complex DNA signal is transported through aquatic environments. For example, using eDNA from two invertebrate species, researchers observed horizontal (i.e. downstream) eDNA transport up to $12.3 \mathrm{~km}$ (Deiner and Altermatt 2014). Vertical transport (i.e. settling) of fish eDNA and accumulation in pond and river sediments was recently described by Turner et al. (2015). The high concentrations of sedimentary fish eDNA they observed also suggest that resuspension of settled eDNA represents an important element of eDNA ecology. Overall, understanding this transport is essential to relating detected eDNA to species presence in both space (i.e. how close was a species to the site of eDNA detection) and time (i.e. how recently was the detected species present). In the case of important conservation applications, being able to connect a positive eDNA detection within specific spatial and temporal boundaries is essential to drawing robust conclusions (Fig. 2c).

\section{Fate: What factors influence eDNA persistence?}

Although the detection of ancient DNA in terrestrial (Willerslev et al. 2003; Lydolph et al. 2005; Haile et al. 2009; Hebsgaard et al. 2009; Jørgensen et al. 2012) and aquatic (Matisoo-Smith et al. 2008; Anderson-Carpenter et al. 2011; Pedersen et al. 2013; Stager et al. 2015) sediments as well as frozen ice cores (Willerslev et al. 2007) testifies to the fact that eDNA from diverse taxa can remain in the environment for a very long period of time under certain conditions, DNA possesses limited chemical stability (Lindahl 1993); in most cases, as soon as it is shed from an organism eDNA begins to degrade (Fig. 1d). Factors which influence the persistence of eDNA in aquatic environments were the focus of a recent review which considered studies across a wide range of disciplines, including detection of macrobial eDNA, microbiology, and water quality assessment via detection of fecal indicator bacteria (Barnes et al. 2014). The persistence of eDNA in terrestrial environments has also been the topic of recent reviews (Nielsen et al. 2007; Levy-Booth et al. 2007). These previous reviews have concluded that the factors which influence eDNA persistence fall into three broad categories: DNA characteristics (i.e. conformation, length, and association with cellular/organellar membranes); the abiotic environment (i.e. light, oxygen, $\mathrm{pH}$, salinity, and the abundance and composition of substrates); and the biotic environment (i.e. the composition and activity of the microbial community and extracellular enzymes).

A summary of major findings related to eDNA persistence is presented in Table 1. As was the case with eDNA transport, much of study of eDNA persistence has been motivated by concern over the release of transgenes from genetically modified organisms. Such studies have examined persistence of genes from transgenic crops in terrestrial soils (Widmer et al. 1996, 1997; Hay et al. 2002; Gebhard and Smalla 2006) and nearby groundwater and riverine environments (Matsui et al. 2001; Zhu 2006). Across these studies, transgenic material remained detectable for long periods of time (days to years) in terrestrial soils, but much shorter periods of detection (hours to days) occurred in aquatic environments (Table 1). More recent studies have focused on eDNA with animal origins. Much of this work has focused on aquatic habitats in laboratory (Dejean et al. 2011; Thomsen et al. 2012b; Goldberg et al. 2013; Barnes et al. 2014; Strickler et al. 2015), while several studies have occurred in aquatic field settings (Thomsen et al. 2012a; Merkes et al. 2014). Turner et al. 2015 presented one of the first comparisons of accumulation of eDNA in open-water versus aquatic sediment samples. Fewer studies have examined eDNA persistence in terrestrial environments (Andersen et al. 2012). In terms of quantifying eDNA persistence, pioneering manipulative studies by Barnes et al. (2014) and Strickler et al. (2015) have measured co-varying environmental conditions in an attempt to understand the drivers of eDNA degradation rates. Recent studies by Barnes et al. (2014), Pilliod et al. (2014), and Strickler et al. (2015) all suggest that environmental conditions play an integral role in the fate of eDNA once it has been shed from an organism.

Overall, the wide range of persistence times in the literature suggest that there is still much to learn about eDNA degradation. An improved understanding of eDNA persistence will benefit our ability to interpret the results of eDNA detection because, as we argued in our previous discussion of eDNA transport through the environment, an understanding of eDNA persistence is critical to delimiting the proximity of a detected organism in space and time (Fig. 2d). Uncovering this knowledge will likely require more research on eDNA itself as well as the interactions between eDNA and its environment.

\section{Future conservation applications of environmental DNA}

In addition to increased understanding of the ecology of eDNA, the accuracy and sensitivity of genetic analysis technology are improving rapidly and commensurately 
Table 1 Summary of major findings on eDNA persistence

\begin{tabular}{|c|c|c|}
\hline Environment & eDNA target & Major findings \\
\hline Terrestrial soil & Bactrian camel (Camelus bactrianus) & $\begin{array}{l}\text { eDNA could be detected in soil samples from a } \\
\text { Danish zoo pen where the species had not been } \\
\text { present for } 6 \text { years }\end{array}$ \\
\hline $\begin{array}{l}\text { Laboratory freshwater } \\
\text { aquaria }\end{array}$ & Common carp (Cyprinus carpio) & $\begin{array}{l}\text { eDNA concentration decreased exponentially; } \\
\text { after } 4 \text { days the probability of detection was } \\
<5 \% \text {. Rare detections occurred as late as } \\
14 \text { days. Degradation rate negatively correlated } \\
\text { with indices of microbial activity (biochemical } \\
\text { oxygen demand, total DNA concentration, and } \\
\text { chlorophyll } a \text { concentration) and pH }\end{array}$ \\
\hline $\begin{array}{l}\text { Laboratory freshwater } \\
\text { mesocosms and small } \\
\text { natural ponds }\end{array}$ & $\begin{array}{l}\text { American bullfrog (Rana catesbeiana) and } \\
\text { Siberian Sturgeon (Acipenser baerii) }\end{array}$ & $\begin{array}{l}\text { eDNA remained detectable with }>5 \% \text { probability } \\
\text { for } 25 \text { days in glass beakers, while fish eDNA in } \\
\text { small ponds demonstrated }>5 \% \text { detection } \\
\text { probability for } 17 \text { days }\end{array}$ \\
\hline Terrestrial soil & Transgenic sugar beet litter (Beta vulgaris) & eDNA remained detectable for 2 years \\
\hline
\end{tabular}

Citation

$\begin{array}{ll}\text { Laboratory freshwater } \\ \begin{array}{l}\text { aquaria and eutrophic 5th } \\ \text { order river }\end{array} & \begin{array}{c}\text { New Zealand mudsnail (Potamopyrgus } \\ \text { antipodarum) }\end{array} \\ \begin{array}{l}\text { Permeable bags in } \\ \text { terrestrial soil }\end{array} & \text { Transgenic poplar leaf material (Populus alba } \\ \text { Lentic environment } & \text { L. } \times \text { Populus grandidentata Michx.) }\end{array}$

Mesocosms floated in experimental ponds and laboratory freshwater aquaria

Laboratory freshwater aquaria

\section{Laboratory freshwater} mesocosms

Laboratory marine aquaria

\section{Outdoor freshwater mesocosms}

Experimental ponds
Silver Carp (Hypophthalmichthys molitrix) carcasses, fecal samples of eagles (Haliaeetus leucocephalus) which had eaten Silver Carp

Idaho giant salamander (Dicamptodon aterrimus)

Bullfrog (Lithobates catesbeianus)

European Flounder Platichthys flesus and Three-spined Stickleback Gasterosteus aculeatus

Common spadefoot toad Pelobates fuscus and great crested newt Triturus cristatus

Bighead and Silver Carp (Hypophthalmichthys spp.)
Andersen

et al.

Barnes

et al.

Dejean

et al.

(2011)

Gebhard

and

Smalla

(2006)

eDNA remained detectable for 21 days following snail removal

Goldberg

et al.

eDNA remained detectable for no longer than 4 months

Hay et al.

Plasmid DNA was undetectable within $170 \mathrm{~h}$ in Matsui untreated water, while no degradation was observed in the presence of antimicrobial agent EDTA. Culling the bacterial community via filtration also resulted in reduced DNA degradation rates

DNA could be recovered from swabbed carcasses for up to 28 days of areal environmental exposure, independent of ambient temperature, humidity, precipitation, and UV exposure. Silver Carp eDNA was also detected from fecal samples of birds who had eaten Silver Carp, and detections occurred from feces which had been deposited up to 30 days prior

eDNA decreased exponentially in light and shaded treatments but was no longer detectable in fullsun treatments after 8 days, detectable in shaded treatments after 11 days, and detectible in refrigerated controls after 18 days

eDNA decreased exponentially but remained detectable $<1-54$ days following organism removal. Higher temperatures and lower $\mathrm{pH}$ decreased degradation rates. UV-B intensity interacted with other factors but appeared to have a positive relationship with eDNA degradation

eDNA from two marine fish species decayed exponentially, resulting in failure to detect eDNA after 0.9 and 6.7 days

et al.

(2001)

Merkes

et al.

(2014)

Pilliod

et al.

Strickler

et al.

(2015)

eDNA persisted 7-14 days following removal of live organisms

Thomsen

et al. (2012a)

Thomsen et al. (2012b)

eDNA was observed in pond sediments for $>130$ days after fish removal, but was not

Turner et al. (2015) 
Table 1 continued

\begin{tabular}{|c|c|c|c|}
\hline Environment & eDNA target & Major findings & Citation \\
\hline Laboratory soil mesocosms & $\begin{array}{l}\text { Transgenic tobacco leaf material and purified } \\
\text { plasmid DNA from Nicotina tabacum cv. } \\
\text { Xanthi }\end{array}$ & $\begin{array}{l}\text { Purified plasmid DNA remained detectable in soil } \\
\text { after } 40 \text { days; the same plasmid within ground } \\
\text { transgenic tobacco leaves was detectable after } \\
120 \text { days. Both trials demonstrated rapid initial } \\
\text { degradation followed by long tails of detection at } \\
\text { low levels }\end{array}$ & $\begin{array}{l}\text { Widmer } \\
\text { et al. } \\
\text { (1996) }\end{array}$ \\
\hline Terrestrial soil & $\begin{array}{l}\text { Transgenic tobacco leaf material (Nicotina } \\
\text { tabacum cv. Xanthi) }\end{array}$ & $\begin{array}{l}\text { eDNA signal of leaf material buried in } 10 \mathrm{~cm} \text { soil } \\
\text { declined rapidly over } 14 \text { days but remained } \\
\text { detectable up to } 77 \text { days }\end{array}$ & $\begin{array}{l}\text { Widmer } \\
\text { et al. } \\
\text { (1997) }\end{array}$ \\
\hline $\begin{array}{l}\text { Groundwater and riverine } \\
\text { environments }\end{array}$ & $\begin{array}{l}\text { Transgenic Bt (Bacillus thuringiensis) corn } \\
\text { plasmid DNA (Zea mays) }\end{array}$ & $\begin{array}{l}\text { Plasmid DNA degraded to undetectable levels } \\
\text { within } 48-96 \text { h in aquatic environments; } \\
\text { however, eDNA remained detectable throughout } \\
\text { a } 192 \text { h experiment when water was sterilized by } \\
\text { autoclave }\end{array}$ & $\begin{array}{l}\text { Zhu } \\
\quad(2006)\end{array}$ \\
\hline
\end{tabular}

with increasing affordability (Shokralla et al. 2012). Although a thorough discussion of the growing technical and methodological considerations of eDNA applications is beyond the scope of the present review, "Appendix" provides an overview of important considerations in study design, sample collection and preparation, eDNA assays, and analysis of eDNA data. Most of the examples of eDNA conservation applications we have presented so far-and indeed most of the macrobial eDNA studies to date-have focused on single-species, presence/absence monitoring with established technologies like endpoint PCR and quantitative PCR (qPCR). Given continuing advancement, a recent perspective piece lauded the potential of expanding the use of eDNA for addressing an expanded list of ecological issues, including diet characterization, description of trophic interactions, and whole-ecosystem biodiversity monitoring (Yoccoz 2012). Here, we outline seven frontiers of eDNA conservation applications representing the cutting edge or intriguing future applications of eDNA technology.

\section{Description of whole communities}

Although the examples we have identified thus far represent applications targeting single species, many researchers have begun to identify multiple species concurrently by using taxonomically general PCR primers paired with cloning and Sanger sequencing (Minamoto et al. 2012) or high-throughput sequencing (HTS; Thomsen et al. 2012b). These efforts have been referred to as metagenomics, metagenetics, metasystematics, or metabarcoding (Taberlet et al. 2012). Ongoing debate about the most apt name for this effort notwithstanding (Esposito and Kirschberg 2014), the ability to use eDNA to detect many species simultaneously inspires considerable conservation appeal (Yoccoz 2012). The ability to survey multiple species within a single sampling effort using eDNA makes surveys more efficient and economical. Furthermore, the use of increasingly general primers or shotgun sequencing (i.e. without taxonomically general PCR) opens up the possibility that managers and researchers do not need to choose target organisms a priori, thus facilitating detection of unexpected endangered or introduced species. Finally, species interactions represent an important consideration for conservation efforts, and understanding the distributions of multiple interacting species in a single survey could contribute to the maintenance of intact communities.

Many studies applying eDNA to the description of groups of organisms or whole communities have begun to emerge. For example, one study used HTS to distinguish multiple earthworm species in soil samples and speculated that similar methods could be used to characterize other soil-dwelling taxa (Bienert et al. 2012). Indeed, other groups of taxa that have successfully been the target of eDNA studies in soil samples include nematodes (Porazinska et al. 2010; Vervoort et al. 2012) and boreal plant communities (Yoccoz et al. 2012). Sequencing of genetic material recovered from leaf litter samples has reflected terrestrial arthropod diversity in China and Vietnam (Yang et al. 2014). Other examples of whole-community eDNA analyses in aquatic environments include survey of fish species in the Monterey Bay Aquarium, California, USA (Kelly et al. 2014b), survey of fish species in aquaria and the Yuma River in Japan (Minamoto et al. 2012), and the detection of fish and bird eDNA in marine water samples in Denmark (Thomsen et al. 2012b). Most recently, research on this frontier has begun to address the substantial uncertainties and artifacts inherent to using PCR and HTS on eDNA, which often exists in trace quantities within the environment (Nguyen et al. 2015). These include falsepositives and false-negatives (Ficetola et al. 2014), PCR and sequencing errors (Schnell et al. 2015), marker 
selection bias (Deagle et al. 2014), and bioinformatic processing artifacts (Rossberg et al. 2014). When uncertainty is handled transparently and rigorously, HTS can obtain robust biodiversity information from eDNA and provide reliable inferences for conservation.

\section{Estimation of organism abundance}

Following many proofs-of-concept of species detection with eDNA, a logical next question to emerge is what information besides presence can be acquired using eDNA. One promising line of inquiry using eDNA is asking whether abundance or concentration of eDNA in environmental samples relate to organismal abundance. For threatened and endangered species with regulations on their accessibility and handling by researchers and managers, quantification with eDNA could provide otherwise unobtainable data. For these and additional species that are difficult to observe, eDNA quantification could provide clues to habitat use and preference, thus identifying spatial conservation priorities such as home ranges and dispersal corridors.

Numerous studies have begun to explore quantification of eDNA as a means of estimating population size or biomass. For example, a study of Common Carp in a Japanese lagoon suggested that Common Carp eDNA concentration related to fish abundance (Takahara et al. 2012). Meanwhile, a Minnesota, USA lake study of Common Carp found similar results, with rate of detection and eDNA concentration correlating positively with fish abundance (Eichmiller et al. 2014). Similar correlations have also been found with multiple amphibian species in Idaho streams (Pilliod et al. 2013) and European ponds (Thomsen et al. 2012a). Metagenetic analysis of soils at zoos and farms (i.e. locations where local species composition is well-known) also reflected community composition and relative biomass of local vertebrate species (Andersen et al. 2012). Distinguishing between eDNA signals of organism abundance and organism proximity (in both space and time) represents an emerging challenge for research along this frontier. Water and air can rapidly transport eDNA across long distances (Deiner and Altermatt 2014; Kraaijeveld et al. 2015), and eDNA decays exponentially in the environment (Barnes et al. 2014). Thus, models that include eDNA production, transport, and decay may improve the ability to infer organism abundance from eDNA quantity.

\section{Population genetics and genomics}

Beyond presence/absence and abundance information, is there more information to be gained from eDNA surveys? The study of population genetics with eDNA samples represents one exciting possibility. Advances in noninvasive genetic methods, such as the collection and population genetic analysis of hair, feathers, eggshells, feces, and other samples have been lauded by the wildlife research and conservation community (Beja-Pereira et al. 2009). However, the leap in complexity when moving from sampling specific materials (e.g. trapped clumps of fur) to the analysis of mixed genetic materials of various quality contained within bulk environmental samples used in eDNA analyses portends considerable hurdles to population genetic and genomic analyses. The same complexity differential applies between, for example, pollen from one plant and a pollen mixture collected by insects.

Whereas previous, primarily metazoan, eDNA assays have depended almost exclusively upon species identification based on mitochondrial DNA (mtDNA), conservation interest in identifying and distinguishing species hybrids, populations, evolutionarily significant units, and individuals based on eDNA will require improved resolution before eDNA methods can adequately assess fine levels of genetic variation or estimate population genetic measures such as effective population size or genetic fixation. Decay and fragmentation of extraorganismal DNA presents one challenge, but noninvasive genetics and paleogenetics have demonstrated remarkable persistence of short nucleic acids (Hofreiter et al. 2001). Perhaps a greater challenge arises from the high probability that multiple individuals and species contribute DNA to any given environmental sample. Such environmentally pooled DNA from an unknown number of individuals complicates distinguishing between individual organisms and estimating classical population genetic parameters, particularly those that rely on allele frequency (Toulza et al. 2012). Standard tools for generating population genetic data also are not generally designed with the high sensitivity and specificity necessary to isolate single-species markers from a complex multi-species mixture. Anecdotally, we have had limited success amplifying $<300 \mathrm{bp}$ microsatellite markers for bigheaded carp (Hypophthalmichthys spp.; Guo et al. 2013) from experimental pond eDNA extracts in which their mtDNA measured ca. 800 copies $/ \mu \mathrm{L}$ (Cameron Turner, unpublished data). Inhibition, off-target primer binding, and low nuclear copy number (relative to mtDNA copies) are among the potential explanations for this failure. We are aware of only two population genetic analyses of macrobial eDNA, and both targeted humans. Kapoor et al. (2014) applied Ion Torrent sequencing to human mtDNA control region amplicons from urban Cincinnati, USA streams, and Afshinnekoo et al. (2015a) applied Illumina shotgun sequencing to eDNA from object surfaces in the New York City, USA subway system. These studies have demonstrated that macrobial eDNA can provide data from rapidly evolving loci, in both organellar and nuclear 
genomes, which coarsely describe geographic patterns of population genetic diversity. Applying similar approaches to wildlife conservation may require considerable population genetic reference data but remains a realistic and exciting possibility.

\section{Functional genetics and genomics}

The decreasing cost of biotechnology, in particular HTS, has enabled functional genomic analysis of species of conservation interest using approaches previously limited to model organisms (Steiner et al. 2013). Practical applications include identification of adaptive or fitness-related loci, monitoring loci related to stress events, and describing the molecular basis of inbreeding depression (Schwartz et al. 2007; Paige 2010). Mitochondrial DNA from one species can comprise just $10^{-8}$ percent of the total eDNA in freshwater (Turner et al. 2014a); thus, low template quantity and background interference present challenges for functional genomic analysis of macrobial eDNA, particularly for single-copy nuclear loci (Morin et al. 2007). However, paleogenetic studies have demonstrated that these types of functional genomic data can be obtained from biomaterial exposed to substantial DNA/RNA decay (Fordyce et al. 2013). Furthermore, microbial metagenomics has paved the way for functional genomic analysis of eDNA, demonstrating how to analyze functional genomic data from complex environmental mixtures of individuals and species (Mendoza et al. 2015). In principle, nothing prevents similar applications for macrobial eDNA, but we are not aware of any studies which have demonstrated functional genomic analysis for macrobiota from degraded, extraorganismal DNA or RNA in environmental mixtures.

Progress in eDNA-based functional genomics will likely follow two complementary paths: (1) using a priori knowledge of functional genomic loci to target specific DNA or RNA fragments in environmental samples (Jaenicke-Després et al. 2003) and (2) using shotgun sequencing of total eDNA or environmental RNA (eRNA) with bioinformatic assignment to taxa, genomes, and functions ( $\mathrm{Su}$ et al. 2014). The first path is immediately accessible to studies using genomic model organisms and sampling designs with predictable and robust differences in genome function (e.g., Robinson et al. 2012). This path will expand to conservation as genomic resources develop for threatened and invasive species (Shafer et al. 2015). The second path is challenged by the large, complex, endosymbiotic, and gene-sparse genomes of eukaryotes compared to prokaryotes (reviewed in Gilbert and Dupont 2011). Nevertheless, accumulation of assembled macrobial genomes (Koepfli et al. 2015) will ease this challenge, and macrobe-inclusive metagenomic analyses of eDNA and eRNA are advancing the necessary bioinformatic tools
(Mendoza et al. 2015). Molecules containing functional genomic information from macrobiota are clearly present in environmental samples. For example, Orsi et al. (2013) reported extraorganismal arthropod RNA from anoxic subseafloor sediments over $10^{4}$ years old. Using functional eDNA/eRNA data for wildlife conservation will require substantial investment to overcome the technical hurdles, but converging advances from many fields inspire optimism along this frontier.

\section{Alternative environmental samples}

As eDNA applications grow to include the frontiers we have described above and additional objectives, so too will interest in applying these technologies in novel conditions and environments. These developments will necessitate creative new approaches to eDNA collection. We have already begun to see imaginative approaches to what constitutes an environmental sample. For example, snow samples containing urine have been used for species and individual identification of French wild canids (Valiere and Taberlet 2000), and traces of saliva left on browsed twigs have been used to identify ungulate species (Nichols et al. 2012). eDNA methods have been applied to bulk-collected carrion flies, not in a study of the flies themselves, but rather as a tool to assess local mammalian biodiversity (Calvignac-Spencer et al. 2013). Similarly, spider web can serve as an eDNA source for both the spider and its prey (Xu et al. 2014). Human eDNA can be found in settled dust and the bodies of small household insects (Toothman et al. 2008; Kester et al. 2010). Researchers have also assessed benthic invertebrate biodiversity by sampling preservative ethanol (Hajibabaei et al. 2012). Although preservative ethanol is not an environmental sample per se, we note the work of Hajibabaei et al. (2012) and others using nondestructive DNA sampling methods (e.g. Thomsen et al. 2009) with excitement in the present section because of the potential for this eDNA-inspired method to enable genetic analysis of museum specimens and other archived samples from the past which may benefit contemporary conservation challenges and ecological understanding.

\section{Remote and autonomous sampling and analysis}

Improving technology to enable remote and autonomous (i.e. without need of constant human input/supervision) eDNA methodologies will greatly expand the potential of eDNA applications to benefit conservation. Already, vast oceanic distances and depths have led marine microbiologists to develop robotic systems for collection of eDNA samples (Scholin 2010). The most sophisticated platform autonomously conducts water filtration, DNA extraction, and genetic assays while deployed and transmits data via 
satellite (Preston et al. 2011). Surveillance of airborne biological hazards has motivated similar developments (Hindson et al. 2005), and engineers have also demonstrated use of unmanned aerial systems (i.e. 'drones') to remotely collect water samples (Ore et al. 2015). In principle, all of these devices are currently applicable to macrobiota, and one air sampling study has reported successful detection of eDNA from diverse animals and plants (Yooseph et al. 2013). Several systems are already commercially available (e.g. http://www.mclanelabs.com); however, high purchase and operating costs may limit dedicated use for conservation efforts. Post-hoc macrobial analysis of microbe-motivated samples from these systems likely represents the first step toward broadening their use across taxa and disciplines. Furthermore, the generic nature of some environmental samples, such as water, makes eDNA sampling amenable to automation, and opportunities abound for integrating genomic data collection and analysis with remote sensing technologies that traditionally focus on electromagnetic, acoustic, or other data. These same features may also open the door to conservation and research efforts at unprecedented geographic scales by engaging citizen scientists to aid with environmental sample collection (Biggs et al. 2014).

\section{Isolating molecules other than DNA from environmental samples}

The field of ecology may be on the cusp of a transformation based on the emergence of metagenomics technologies; Poole et al. (2012) have coined the term "ecosystomics" to describe the upcoming flood of affordable, easily-collected genetic information about individuals, populations, and communities. Our review - and indeed most of the research relevant to the scope of this review to date-has focused on detecting DNA within the environment as an indicator of species presence. However, other biological molecules may also offer opportunities for conservation and research. For example, RNA is generally less stable than DNA, and for this reason its degradation has been used by forensic scientists to estimate the time since deposition of biological material (Bremmer et al. 2012). Therefore, assays targeting eRNA may provide narrower spatiotemporal inferences of organism presence or abundance than eDNA. Forensic scientists have used messenger RNA (mRNA) to identify different body fluids left at crime scenes (Vennemann and Koppelkamm 2010), which suggests mRNA could provide information about the physiological origin of biomaterial in environmental samples. Microbial metatranscriptomics provides guidance for using HTS technologies to characterize eRNA (Shi et al. 2009). Quantifying proteins in the environment combined with a knowledge of proteomics may be useful as an indicator of organismal activity or ecosystem health, as the activation of certain genes could indicate responses to environmental stimuli. Microbial metaproteomics has demonstrated how community-scale analysis of environmental proteins can be accomplished (Maron et al. 2007), and the collection and analysis of intact polar membrane lipids has been used to describe microbial community composition in sediment and water column samples (Schubotz et al. 2009). Thus, DNA may soon represent one of many biological materials collected and analyzed from environmental samples.

\section{Conclusion}

eDNA analysis represents an emerging tool for research and conservation. Already, eDNA tools have been applied in diverse systems, including terrestrial, freshwater, and marine environments. The principles of detecting genetic material within environmental samples were first utilized in the field of microbiology, and today similar techniques continue to be expanded to include an ever-increasing breadth of macrobial organisms. As technology continues to rapidly improve and costs decline, the list of potential future conservation and research applications of eDNA is genuinely exciting. In the present review, we have outlined the frontiers of conservation-focused eDNA applications in which we see the most potential for growth, including the use of eDNA for census or measuring biomass of populations, population genetic and genomic analyses via eDNA, inclusion of other indicator biomolecules such as environmental RNA or proteins, and expanded technology enabling automation of sample collection and analysis as well as sampling of a wide array of creative environmental samples. However, a more complete understanding of what we have termed the ecology of eDNA - its origin, state, transport, and fate within the environment-is needed to inform eDNA collection and analysis as well as maximize the research and conservation potential of future eDNA applications (Figs. 1, 2). The application of eDNA-based technology is already beginning to influence conservation, management, and policy decisions, despite existing uncertainty (Kelly et al. 2014a). Nevertheless, there is much work to be done to continue close the gap between research and management considering the application and interpretation of genetic methods including eDNA applications (Darling 2015), and the present review has provided a framework to guide research and organize understanding as eDNA frontiers continue to advance.

Acknowledgments Thank you to Sean Hoban for encouragement to prepare this review. Comments from Sean Hoban and three anonymous reviewers greatly improved the manuscript. The ideas presented herein have benefited from discussions with many individuals, especially Robert Everhart, Christopher Jerde, and David Lodge. Rebecca 
Turner assisted with figures. Figure icons used under CC BY 3.0 license are from Mallory Hawes (fish), Olivier Guin (test tube), Chris Dawson (wave), and Pratyush Tewari (hourglass). CRT was supported by NSF IGERT grant award \#0504495 to the GLOBES graduate training program at the University of Notre Dame. Mention of specific products or trade names have been for illustrative purposes only and should not be considered as an endorsement.

Open Access This article is distributed under the terms of the Creative Commons Attribution 4.0 International License (http://crea tivecommons.org/licenses/by/4.0/), which permits unrestricted use, distribution, and reproduction in any medium, provided you give appropriate credit to the original author(s) and the source, provide a link to the Creative Commons license, and indicate if changes were made.

\section{Appendix: eDNA techniques and implications for conservation genetics}

Our focus on the ecology of eDNA puts a comprehensive discussion of techniques beyond the scope of this paper. However, thoughtful selection and transparent presentation of eDNA methods represent important considerations as eDNA applications and the field of researchers exploring the ecology of eDNA continue to expand. Here we briefly describe a few examples.

\section{Study design}

Eukaryotes have up to three separate genomes: nuclear, mitochondrial, and plastid. The structure, function, inheritance, and evolution of these genomes varies across the tree of life (e.g. Zouros et al. 1994) and creates important differences for their use in identifying species or populations from DNA sequence (Steele and Pires 2011). In addition to these features, eDNA studies need to consider the anatomical location and physiological shedding of different genomes in target taxa. For example, the quantity of chloroplasts in angiosperm pollen varies across species, making the choice of plastid or nuclear genomes important for studies of plant eDNA in air, sediment, or pollinator forage (Bennett and Parducci 2006; Kraaijeveld et al. 2015; Richardson et al. 2015). Metazoan eDNA studies have tended to use mitogenome regions because of the higher number of mitochondrial versus nuclear genomes per cell (Rees et al. 2015); however, eukaryotic ribosomal DNA copy number per nuclear genome can reach 19,300 in animals and 26,048 in plants (Prokopowich et al. 2003) numbers which are comparable to the largest numbers of mitogenomes per cell (e.g., 22,000; Caldwell et al. 2011). The value of mtDNA for eDNA studies may thus have more to do with its structural resistance to degradation than its cellular copy number (discussed in Turner et al. 2014a).
Using multiple regions from one or more genomes can improve target detection (Evans et al. 2015).

\section{Sample collection and preparation}

Macrobial DNA can be found almost everywhere, but the behavior of target organisms, ecology of eDNA, and study goals determine which methods are optimal for collecting and preparing samples. For example, stream mtDNA concentration from a fully aquatic amphibian was significantly higher in breeding season than other months (Spear et al. 2015). Increased eDNA production from gamete release and lower DNA degradation in intact gametes are likely explanations. Thus, an eDNA survey to identify reproducing populations might include high-frequency temporal sampling and water filter pore size matched to gamete size. Optimal preservation and extraction of target DNA from environmental samples will also vary across taxa and environments. For example, pollen DNA extraction may require crushing pollen grains (Kraaijeveld et al. 2015), and total sediment DNA extraction benefits from chemical desorption of sediment-adsorbed DNA molecules (Yankson and Steck 2009). Thus, a "one size fits all" approach is not feasible for collecting and preparing eDNA samples, and attention to organismal and environmental idiosyncrasies should inform methodological choices.

\section{eDNA assays}

Narrow assays target one species or genus using DNA amplification technology such as real-time quantitative PCR or digital PCR (Doi et al. 2015). Oligonucleotides are designed to exclusively amplify the taxon, allowing conclusions about target DNA presence and quantity immediately after amplification (Turner et al. 2014b). Broad assays use high-throughput sequencing (HTS) or microarrays to target large clades such as flowering plants or cellular organisms (Vuong et al. 2013). DNA amplification or hybridization can enrich for a target clade prior to sequencing, or direct shotgun sequencing can be used to generate sequence data from all organisms (Shokralla et al. 2012). Post-sequencing bioinformatic analysis provides conclusions about target DNA presence and quantity. A holistic consideration of the ecology of eDNA (Fig. 1) shows how various processes can produce detection or nondetection, thus rigorous precautions and quality controls are needed to reduce uncertainty(Murray et al. 2015). Empirical studies of forensic DNA mixture interpretation demonstrate how observer effects (i.e. the human tendency to interpret data in a manner consistent with one's expectations) create subjectivity and bias (Dror and Hampikian 
2011), and users of eDNA assays may benefit from considering this phenomenon.

\section{Analysis of eDNA data}

Bioinformatic analysis of HTS data from eDNA samples represents a complex and rapidly changing landscape (Edgar and Flyvbjerg 2015). Macrobial eDNA studies use massive datasets to evaluate low abundance sequences from unseen taxa, thus susceptibility to artifacts such as sample contamination (Lusk 2014), amplification errors (Schnell et al. 2015), sequencing errors (Robasky et al. 2014), computational artifacts (Rossberg et al. 2014), and inaccurate taxonomic assignment (Afshinnekoo et al. 2015 b), is high. Mendoza et al. (2015) provide a useful overview for navigating these challenges. From our own experience applying HTS to assay macrobial eDNA, we recommend using negative controls with carrier biomaterial (Xu et al. 2009) and positive controls with mock community DNA (Schloss et al. 2011). Different perspectives are still emerging about how control data should be used to "correct" co-sequenced eDNA data (Nguyen et al. 2015), but the transparent and self-critical cognitive approach recommended by Gilbert et al. (2005) for ancient DNA is highly applicable to all eDNA studies, particularly those with conservation applications where substantial economic and legal consequences may result (Kelly 2014).

\section{References}

Afshinnekoo E, Meydan C, Chowdhury S et al (2015a) Geospatial resolution of human and bacterial diversity with city-scale metagenomics. Cell Syst 1:72-87

Afshinnekoo E, Meydan C, Chowdhury S et al (2015b) Modern methods for delineating metagenomic complexity. Cell Syst 1:6-7. doi:10.1016/j.cels.2015.07.007

Andersen K, Bird KL, Rasmussen M et al (2012) Meta-barcoding of "dirt" DNA from soil reflects vertebrate biodiversity. Mol Ecol 21:1966-1979. doi:10.1111/j.1365-294X.2011.05261.x

Anderson-Carpenter LL, McLachlan JS, Jackson ST et al (2011) Ancient DNA from lake sediments: bridging the gap between paleoecology and genetics. BMC Evol Biol 11:30. doi:10.1186/ 1471-2148-11-30

Barnes MA, Turner CR, Jerde CL et al (2014) Environmental conditions influence eDNA persistence in aquatic systems. Environ Sci Technol 48:1819-1827. doi:10.1021/es404734p

Beja-Pereira A, Oliveira R, Alves PC et al (2009) Advancing ecological understandings through technological transformations in noninvasive genetics. Mol Ecol Resour 9:1279-1301. doi:10. 1111/j.1755-0998.2009.02699.x

Bennett KD, Parducci L (2006) DNA from pollen: principles and potential. Holocene 16:1031-1034. doi:10.1177/ 0959683606069383

Bienert F, De Danieli S, Miquel C et al (2012) Tracking earthworm communities from soil DNA. Mol Ecol 21:2017-2030. doi:10. 1111/j.1365-294X.2011.05407.x
Biggs J, Ewald N, Valentini A et al (2014) Using eDNA to develop a national citizen science-based monitoring programme for the great crested newt (Triturus cristatus). Biol Conserv 183:19-28. doi:10.1016/j.biocon.2014.11.029

Blanchet S (2012) The use of molecular tools in invasion biology: an emphasis on freshwater ecosystems. Fish Manag Ecol 19:120-132. doi:10.1111/j.1365-2400.2011.00832.x

Bohmann K, Evans A, Gilbert MTP et al (2014) Environmental DNA for wildlife biology and biodiversity monitoring. Trends Ecol Evol 29:358-367. doi:10.1016/j.tree.2014.04.003

Bremmer RH, De Bruin KG, Van Gemert MJC et al (2012) Forensic quest for age determination of bloodstains. Forensic Sci Int 216:1-11. doi:10.1016/j.forsciint.2011.07.027

Briski E, Cristescu ME, Bailey SA, MacIsaac HJ (2011) Use of DNA barcoding to detect invertebrate invasive species from diapausing eggs. Biol Invasions 13:1325-1340. doi:10.1007/s10530010-9892-7

Caldwell J, Payment P, Villemur R (2011) Mitochondrial DNA as source tracking markers of fecal contamination. In: Hagedorn $\mathrm{C}$, Blanch AR, Harwood VJ (eds) Microbial source tracking: methods, applications, and case studies. Springer, New York, pp 229-250

Calvignac-Spencer S, Merkel K, Kutzner N et al (2013) Carrion flyderived DNA as a tool for comprehensive and cost-effective assessment of mammalian biodiversity. Mol Ecol 22:915-924. doi: $10.1111 / \mathrm{mec} .12183$

Collins RA, Armstrong KF, Holyoake AJ, Keeling S (2012) Something in the water: biosecurity monitoring of ornamental fish imports using environmental DNA. Biol Invasions 15:1209-1215. doi:10.1007/s10530-012-0376-9

Darling JA (2015) Genetic studies of aquatic biological invasions: closing the gap between research and management. Biol Invasions 17:951-971. doi:10.1007/s10530-014-0726-x

Darling JA, Tepolt CK (2008) Highly sensitive detection of invasive shore crab (Carcinus maenas and Carcinus aestuarii) larvae in mixed plankton samples using polymerase chain reaction and restriction fragment length polymorphisms (PCR-RFLP). Aquat Invasions 3:141-152. doi:10.3391/ai.2008.3.2.4

Deagle BE, Jarman SN, Coissac E et al (2014) DNA metabarcoding and the cytochrome c oxidase subunit I marker: not a perfect match. Biol Lett 10:20140562

Deiner K, Altermatt F (2014) Transport distance of invertebrate environmental DNA in a natural river. PLoS ONE 9:e88786. doi:10.1371/journal.pone.0088786

Deiner K, Walser J, Mächler E, Altermatt F (2015) Choice of capture and extraction methods affect detection of freshwater biodiversity from environmental DNA. Biol Conserv 183:53-63. doi:10. 1016/j.biocon.2014.11.018

Dejean T, Valentini A, Duparc A et al (2011) Persistence of environmental DNA in freshwater ecosystems. PLoS ONE 6:e23398. doi:10.1371/journal.pone.0023398

Díaz-Ferguson EE, Moyer GR (2014) History, applications, methodological issues and perspectives for the use environmental DNA (eDNA) in marine and freshwater environments. Rev Biol Trop 62:1273-1284

Doi H, Uchii K, Takahara T et al (2015) Use of droplet digital PCR for estimation of fish abundance and biomass in environmental DNA surveys. PLoS ONE 10:e0122763. doi:10.1371/journal. pone. 0122763

Douville M, Gagne F, Blaise C, Andre C (2007) Occurrence and persistence of Bacillus thuringiensis $(\mathrm{Bt})$ and transgenic $\mathrm{Bt}$ corn cry $1 \mathrm{Ab}$ gene from an aquatic environment. Ecotoxicol Environ Saf 66:195-203. doi:10.1016/j.ecoenv.2006.01.002

Dror IE, Hampikian G (2011) Subjectivity and bias in forensic DNA mixture interpretation. Sci Justice 51:204-208. doi:10.1016/j. scijus.2011.08.004 
Edgar RC, Flyvbjerg H (2015) Error filtering, pair assembly and error correction for next-generation sequencing reads. Bioinformatics. doi:10.1093/bioinformatics/btv401

Egan SP, Barnes MA, Hwang C et al (2013) Rapid invasive species detection by combining environmental DNA with light transmission spectroscopy. Conserv Lett 6:402-409. doi:10.1111/ conl.12017

Eichmiller JJ, Bajer PG, Sorensen PW (2014) The relationship between the distribution of Common Carp and their environmental DNA in a small lake. PLoS ONE 9:e112611. doi:10. 1371/journal.pone.0112611

Esposito A, Kirschberg M (2014) How many 16S-based studies should be included in a metagenomic conference? It may be a matter of etymology. FEMS Microbiol Lett 351:145-146. doi:10.1111/1574-6968.12375

Evans NT, Olds BP, Turner CR et al (2015) Quantification of mesocosm fish and amphibian species diversity via eDNA metabarcoding. Mol Ecol Resour. doi:10.1111/1755-0998.12433

Ficetola GF, Miaud C, Pompanon F, Taberlet P (2008) Species detection using environmental DNA from water samples. Biol Lett 4:423-425. doi:10.1098/rsbl.2008.0118

Ficetola GF, Pansu J, Bonin A et al (2014) Replication levels, false presences and the estimation of the presence/absence from eDNA metabarcoding data. Mol Ecol Resour. doi:10.1111/1755-0998.12338

Foote AD, Thomsen PF, Sveegaard S et al (2012) Investigating the potential use of environmental DNA (eDNA) for genetic monitoring of marine mammals. PLoS ONE 7:e41781. doi:10. 1371/journal.pone.0041781

Foppen JW, Orup C, Adell R et al (2011) Using multiple artificial DNA tracers in hydrology. Hydrol Process 25:3101-3106. doi:10.1002/hyp. 8159

Fordyce SL, Ávila-Arcos MC, Rasmussen M et al (2013) Deep sequencing of RNA from ancient maize kernels. PLoS ONE 8:1-9. doi:10.1371/journal.pone.0050961

Gebhard F, Smalla K (2006) Monitoring field releases of genetically modified sugar beets for persistence of transgenic plant DNA and horizontal gene transfer. FEMS Microbiol Ecol 28:261-272

Gilbert JA, Dupont CL (2011) Microbial metagenomics: beyond the genome. Ann Rev Mar Sci 3:347-371. doi:10.1146/annurevmarine-120709-142811

Gilbert MTP, Bandelt HJ, Hofreiter M, Barnes I (2005) Assessing ancient DNA studies. Trends Ecol Evol 20:541-544. doi:10. 1016/j.tree.2005.07.005

Goldberg CS, Sepulveda A, Ray A et al (2013) Environmental DNA as a new method for early detection of New Zealand mudsnails (Potamopyrgus antipodarum). Freshw Sci 32:792-800. doi:10. 1899/13-046.1

Guo W, Yu X, Tong J (2013) Development of 134 novel polynucleotide-repeat microsatellite markers in silver carp (Hypophthalmichthys molitrix). Conserv Genet Resour 5:525-528. doi:10.1007/s12686-012-9843-y

Haile J, Froese DG, MacPhee RDE et al (2009) Ancient DNA reveals late survival of mammoth and horse in interior Alaska. Proc Natl Acad Sci 106:22363-22368

Hajibabaei M, Spall JL, Shokralla S, van Konynenburg S (2012) Assessing biodiversity of a freshwater benthic macroinvertebrate community through non-destructive environmental barcoding of DNA from preservative ethanol. BMC Ecol 12:28. doi:10.1186/ 1472-6785-12-28

Harvey J, Hoy M, Rodriguez R (2009) Molecular detection of native and invasive marine invertebrate larvae present in ballast and open water environmental samples collected in puget sound. J Exp Mar Biol Ecol 369:93-99. doi:10.1016/j.jembe.2008.10.030

Hay I, Morency M, Séguin A (2002) Assessing the persistence of DNA in decomposing leaves of genetically modified poplar trees. Can J For Res 32:977-982. doi:10.1139/X02-017
Hebsgaard MB, Gilbert MTP, Arneborg J et al (2009) "The Farm Beneath the Sand" - an archaeological case study on ancient "dirt" DNA. Antiquity 83:430-444. doi:10.1017/ S0003598X00098537

Hindson BJ, Makarewicz AJ, Setlur US et al (2005) APDS: the autonomous pathogen detection system. Biosens Bioelectron 20:1925-1931. doi:10.1016/j.bios.2004.09.027

Hofreiter M, Serre D, Poinar HN et al (2001) Ancient DNA. Nat Rev Genet 2:353-359. doi:10.1038/35072071

Jaenicke-Després V, Buckler ES, Smith BD et al (2003) Early allelic selection in maize as revealed by ancient DNA. Science 302:1206-1208. doi:10.1126/science. 1089056

Jerde CL, Mahon AR, Chadderton WL, Lodge DM (2011) "Sightunseen" detection of rare aquatic species using environmental DNA. Conserv Lett 4:150-157. doi:10.1111/j.1755-263X.2010.00158.x

Jørgensen T, Haile J, Möller P et al (2012) A comparative study of ancient sedimentary DNA, pollen and macrofossils from permafrost sediments of northern Siberia reveals long-term vegetational stability. Mol Ecol 21:1989-2003. doi:10.1111/j. 1365-294X.2011.05287.x

Kapoor V, DeBry RW, Boccelli DL, Wendell D (2014) Sequencing human mitochondrial hypervariable region II as a molecular fingerprint for environmental waters. Environ Sci Technol 48:10648-10655. doi:10.1021/es503189g

Kelly RP (2014) Will more, better, cheaper, and faster monitoring improve environmental management? Environ Law 44:1111-1147. doi:10.2139/ssrn.2408550

Kelly RP, Port JA, Yamahara KM et al (2014a) Harnessing DNA to improve environmental management. Science 344:1455-1456. doi:10.1126/science. 1251156

Kelly RP, Port JA, Yamahara KM, Crowder LB (2014b) Using environmental DNA to census marine fishes in a large mesocosm. PLoS ONE 9:e86175. doi:10.1371/journal.pone.0086175

Kester KM, Toothman MH, Brown BL et al (2010) Recovery of environmental human DNA by insects. J Forensic Sci 55:1543-1551. doi:10.1111/j.1556-4029.2010.01500.x

Klymus KE, Richter CA, Chapman DC, Paukert C (2014) Quantification of eDNA shedding rates from invasive bighead carp Hypophthalmichthys nobilis and silver carp Hypophthalmichthys molitrix. Biol Conserv 183:77-84. doi:10.1016/j.biocon.2014.11.020

Koepfli KP, Paten B, Genome $10 \mathrm{~K}$ Community of Scientists, O'Brien SJ (2015) The Genome 10 K Project: a way forward. Annu Rev Anim Biosci 3:57-111. doi:10.1146/annurev-animal090414-014900

Kraaijeveld K, de Weger LA, García MV et al (2015) Efficient and sensitive identification and quantification of airborne pollen using next-generation DNA sequencing. Mol Ecol Resour 15:8-16. doi:10.1111/1755-0998.12288

Levy-Booth D, Campbell R, Gulden R et al (2007) Cycling of extracellular DNA in the soil environment. Soil Biol Biochem 39:2977-2991. doi:10.1016/j.soilbio.2007.06.020

Li F, Mahon AR, Barnes MA et al (2011) Quantitative and rapid DNA detection by laser transmission spectroscopy. PLoS ONE 6:e29224. doi:10.1371/journal.pone.0029224

Lindahl T (1993) Instability and decay of the primary structure of DNA. Nature 362:709-715

Lodge DM, Williams S, MacIsaac HJ et al (2006) Biological invasions: recommendations for US policy and management. Ecol Appl 16:2035-2054

Lodge DM, Turner CR, Jerde CL et al (2012) Conservation in a cup of water: estimating biodiversity and population abundance from environmental DNA. Mol Ecol 21:2555-2558. doi:10.1111/j. 1365-294X.2012.05600.x

Lusk RW (2014) Diverse and widespread contamination evident in the unmapped depths of high throughput sequencing data. PLoS ONE 9:e110808 
Lydolph MC, Jacobsen J, Arctander P et al (2005) Beringian paleoecology inferred from permafrost-preserved fungal DNA. Appl Environ Microbiol 71:1012-1017. doi:10.1128/AEM.71.2.1012

Mächler E, Deiner K, Steinmann P, Altermatt F (2014) Utility of environmental DNA for monitoring rare and indicator macroinvertebrate species. Freshw Sci 33:1174-1183. doi:10.1086/ 678128

Mahon AR, Barnes MA, Li F et al (2012) DNA-based species detection capabilities using laser transmission spectroscopy. J R Soc Interface 10:20120637. doi:10.1098/rsif.2012.0637

Mahon AR, Jerde CL, Galaska M et al (2013) Validation of eDNA surveillance sensitivity for detection of Asian carps in controlled and field experiments. PLoS ONE 8:e58316. doi:10.1371/ journal.pone. 0058316

Mahon AR, Nathan LR, Jerde CL (2014) Meta-genomic surveillance of invasive species in the bait trade. Conserv Genet Resour 6:563-567. doi:10.1007/s12686-014-0213-9

Maron PA, Ranjard L, Mougel C, Lemanceau P (2007) Metaproteomics: a new approach for studying functional microbial ecology. Microb Ecol 53:486-493. doi:10.1007/s00248-0069196-8

Martellini A, Payment P, Villemur R (2005) Use of eukaryotic mitochondrial DNA to differentiate human, bovine, porcine and ovine sources in fecally contaminated surface water. Water Res 39:541-548. doi:10.1016/j.watres.2004.11.012

Maruyama A, Nakamura K, Yamanaka H et al (2014) The release rate of environmental DNA from juvenile and adult fish. PLoS ONE 9:e114639. doi:10.1371/journal.pone.0114639

Matisoo-Smith E, Roberts K, Welikala N et al (2008) Recovery of DNA and pollen from New Zealand lake sediments. Quat Int 184:139-149. doi:10.1016/j.quaint.2007.09.013

Matsui K, Honjo M, Kawabata Z (2001) Estimation of the fate of dissolved DNA in thermally stratified lake water from the stability of exogenous plasmid DNA. Aquat Microb Ecol 26:95-102

Mendoza MLZ, Sicheritz-Ponten T, Gilbert MTP (2015) Environmental genes and genomes: understanding the differences and challenges in the approaches and software for their analyses. Brief Bioinform. doi:10.1093/bib/bbv001

Merkes CM, McCalla SG, Jensen NR et al (2014) Persistence of DNA in carcasses, slime and avian feces may affect interpretation of environmental DNA data. PLoS ONE 9:e113346. doi:10.1371/ journal.pone. 0113346

Minamoto T, Yamanaka H, Takahara T et al (2012) Surveillance of fish species composition using environmental DNA. Limnology 13:193-197. doi:10.1007/s10201-011-0362-4

Morin PA, Hedrick NM, Robertson KM, Leduc CA (2007) Comparative mitochondrial and nuclear quantitative PCR of historical marine mammal tissue, bone, baleen, and tooth samples. Mol Ecol Notes 7:404-411. doi:10.1111/j.1471-8286.2007.01699.x

Moyer GR, Díaz-Ferguson E, Hill JE, Shea C (2014) Assessing environmental DNA detection in controlled lentic systems. PLoS ONE 9:e103767. doi:10.1371/journal.pone.0103767

Murray DC, Coghlan ML, Bunce M (2015) From benchtop to desktop: important considerations when designing amplicon sequencing workflows. Plos ONE 10:e0124671. doi:10.1371/ journal.pone. 0124671

Nguyen NH, Smith D, Peay K, Kennedy P (2015) Parsing ecological signal from noise in next generation amplicon sequencing. New Phytol 205:1389-1393. doi:10.1111/nph.12923

Nichols RV, Königsson H, Danell K, Spong G (2012) Browsed twig environmental DNA: diagnostic PCR to identify ungulate species. Mol Ecol Resour 12:983-989. doi:10.1111/j.17550998.2012.03172.x
Nielsen KM, Johnsen PJ, Bensasson D, Daffonchio D (2007) Release and persistence of extracellular DNA in the environment. Environ Biosaf Res 6:37-53. doi:10.1051/ebr

Ogram A, Sayler GS, Barkay T (1987) The extraction and purification of microbial DNA from sediments. J Microbiol Methods 7:57-66. doi:10.1016/0167-7012(87)90025-X

Olson ZH, Briggler JT, Williams RN (2012) An eDNA approach to detect eastern hellbenders (Cryptobranchus a. alleganiensis) using samples of water. Wildl Res 39:629-636. doi:10.1071/WR12114

Ore J, Elbaum S, Burgin A et al (2015) Autonomous aerial water sampling. In: Mejias L, Corke P, Roberts J (eds) Field and service robotics. Springer International Publishing, Switzerland, pp 137-151

Orsi W, Biddle JF, Edgcomb V (2013) Deep sequencing of subseafloor eukaryotic rRNA reveals active fungi across marine subsurface provinces. PLoS ONE 8:e56335. doi:10.1371/journal. pone. 0056335

Paige KN (2010) The functional genomics of inbreeding depression: a new approach to an old problem. Bioscience 60:267-277. doi:10. 1525/bio.2010.60.4.5

Pedersen MW, Ginolhac A, Orlando L et al (2013) A comparative study of ancient environmental DNA to pollen and macrofossils from lake sediments reveals taxonomic overlap and additional plant taxa. Quat Sci Rev 75:161-168. doi:10.1016/j.quascirev. 2013.06.006

Pedersen MW, Overballe-Petersen S, Ermini L et al (2015) Ancient and modern environmental DNA. Philos Trans R Soc London Ser B Biol Sci 370:20130383. doi:10.1098/rstb.2013.0383

Piaggio AJ, Engeman RM, Hopken MW et al (2014) Detecting an elusive invasive species: a diagnostic PCR to detect Burmese python in Florida waters and an assessment of persistence of environmental DNA. Mol Ecol Resour 14:374-380. doi:10.1111/ 1755-0998.12180

Pilliod DS, Goldberg CS, Arkle RS, Waits LP (2013) Estimating occupancy and abundance of stream amphibians using environmental DNA from filtered water samples. Can J Fish Aquat Sci 1130:1123-1130

Pilliod DS, Goldberg CS, Arkle RS, Waits LP (2014) Factors influencing detection of eDNA from a stream-dwelling amphibian. Mol Ecol Resour 14:109-116. doi:10.1111/1755-0998.12159

Poole AM, Stouffer DB, Tylianakis JM (2012) "Ecosystomics": ecology by sequencer. Trends Ecol Evol 27:309-310. doi:10. 1016/j.tree.2012.03.008

Porazinska DL, Giblin-Davis RM, Esquivel A et al (2010) Ecometagenetics confirm high tropical rainforest nematode diversity. Mol Ecol 19:5521-5530. doi:10.1111/j.1365-294X.2010.04891.x

Poté J, Ackermann R, Wildi W (2009a) Plant leaf mass loss and DNA release in freshwater sediments. Ecotoxicol Environ Saf 72:1378-1383. doi:10.1016/j.ecoenv.2009.04.010

Poté J, Mavingui P, Navarro E et al (2009b) Extracellular plant DNA in Geneva groundwater and traditional artesian drinking water fountains. Chemosphere 75:498-504. doi:10.1016/j.chemo sphere.2008.12.048

Preston CM, Harris A, Ryan JP et al (2011) Underwater application of quantitative PCR on an ocean mooring. PLoS ONE 6:e22522. doi:10.1371/journal.pone.0022522

Prokopowich CD, Gregory TR, Crease TJ (2003) The correlation between rDNA copy number and genome size in eukaryotes. Genome 46:48-50. doi:10.1139/g02-103

Rees HC, Bishop K, Middleditch DJ et al (2014a) The application of eDNA for monitoring of the Great Crested Newt in the UK. Ecol Evol 4:4023-4032. doi:10.1002/ece3.1272

Rees HC, Maddison BC, Middleditch DJ et al (2014b) The detection of aquatic animal species using environmental DNA - a review 
of eDNA as a survey tool in ecology. J Appl Ecol 51:1450-1459. doi:10.1111/1365-2664.12306

Rees HC, Gough KC, Middleditch DJ et al (2015) Applications and limitations of measuring environmental DNA as indicators of the presence of aquatic animals. J Appl Ecol 52:827-831. doi:10. 1111/1365-2664.12467

Richardson RT, Lin C, Sponsler DB et al (2015) Application of ITS2 metabarcoding to determine the provenance of pollen collected by honey bees in an agroecosystem. Appl Plant Sci 3:1400066. doi:10.3732/apps.1400066

Robasky K, Lewis NE, Church GM (2014) The role of replicates for error mitigation in next-generation sequencing. Nat Rev Genet 15:55-62. doi:10.1038/nrg3655

Robinson SJ, Samuel MD, Johnson CJ et al (2012) Emerging prion disease drives host selection in a wildlife population. Ecol Appl 22:1050-1059. doi:10.1890/11-0907.1

Rossberg AG, Rogers T, McKane AJ (2014) Current noise-removal methods can create false signals in ecogenomic data. Proc R Soc B 281:20140191. doi:10.1098/rspb.2014.0191

Schloss PD, Gevers D, Westcott SL (2011) Reducing the effects of PCR amplification and sequencing artifacts on $16 \mathrm{~s}$ rRNA-based studies. PLoS ONE. doi:10.1371/journal.pone.0027310

Schnell IB, Bohmann K, Gilbert MTP (2015) Tag jumps illuminated-reducing sequence-to-sample misidentifications in metabarcoding studies. Mol Ecol Resour. doi:10.1111/17550998.12402

Scholin CA (2010) What are "ecogenomic sensors?" A review and thoughts for the future. Ocean Sci 6:51-60. doi:10.5194/os-6-512010

Schubotz F, Wakeham SG, Lipp JS et al (2009) Detection of microbial biomass by intact polar membrane lipid analysis in the water column and surface sediments of the Black Sea. Environ Microbiol 11:2720-2734. doi:10.1111/j.1462-2920.2009.01999.x

Schwartz MK, Luikart G, Waples RS (2007) Genetic monitoring as a promising tool for conservation and management. Trends Ecol Evol 22:25-33. doi:10.1016/j.tree.2006.08.009

Shafer ABA, Wolf JBW, Alves PC et al (2015) Genomics and the challenging translation into conservation practice. Trends Ecol Evol 30:78-87. doi:10.1016/j.tree.2014.11.009

Shi Y, Tyson GW, DeLong EF (2009) Metatranscriptomics reveals unique microbial small RNAs in the ocean's water column. Nature 459:266-269. doi:10.1038/nature08055

Shokralla S, Spall JL, Gibson JF, Hajibabaei M (2012) Nextgeneration sequencing technologies for environmental DNA research. Mol Ecol 21:1794-1805. doi:10.1111/j.1365-294X. 2012.05538.x

Sigsgaard EE, Carl H, Moller PR, Thomsen PF (2015) Monitoring the near-extinct European weather loach in Denmark based on environmental DNA from water samples. Biol Conserv 183:46-52. doi:10.1016/j.biocon.2014.11.023

Spear SF, Groves JD, Williams LA, Waits LP (2015) Using environmental DNA methods to improve detectability in a hellbender (Cryptobranchus alleganiensis) monitoring program. Biol Conserv 183:38-45. doi:10.1016/j.biocon.2014.11. 016

Stager JC, Sporn LA, Johnson M, Regalado S (2015) Of paleo-genes and perch: what if an "alien" is actually a native? PLoS ONE 10:e0119071. doi:10.1371/journal.pone.0119071

Steele PR, Pires JC (2011) Biodiversity assessment: state-of-the-art techniques in phylogenomics and species identification. Am J Bot 98:415-425. doi:10.3732/ajb.1000296

Stein ED, Martinez MC, Stiles S et al (2014) Is DNA barcoding actually cheaper and faster than traditional morphological methods: results from a survey of freshwater bioassessment efforts in the United States? PLoS ONE 9:e95525. doi:10.1371/ journal.pone.0095525
Steiner CC, Putnam AS, Hoeck PE, Ryder OA (2013) Conservation genomics of threatened animal species. Annu Rev Anim Biosci 1:261-281. doi:10.1146/annurev-animal-031412-103636

Strickler KM, Fremier AK, Goldberg CS (2015) Quantifying effects of UV-B, temperature, and $\mathrm{pH}$ on eDNA degradation in aquatic microcosms. Biol Conserv 183:85-92. doi:10.1016/j.biocon. 2014.11.038

Su X, Pan W, Song B et al (2014) Parallel-META 2.0: enhanced metagenomic data analysis with functional annotation, high performance computing and advanced visualization. PLoS ONE 9:e89323. doi:10.1371/journal.pone.0089323

Sutherland WJ, Bardsley S, Clout M et al (2013) A horizon scan of global conservation issues for 2013. Trends Ecol Evol 28:16-22. doi:10.1016/j.tree.2012.10.022

Taberlet P, Coissac E, Hajibabaei M, Rieseberg LH (2012) Environmental DNA. Mol Ecol 21:1789-1793. doi:10.1111/j.1365294X.2012.05542.x

Takahara T, Minamoto T, Yamanaka H et al (2012) Estimation of fish biomass using environmental DNA. PLoS ONE 7:e35868. doi:10.1371/journal.pone.0035868

Takahara T, Minamoto T, Doi H (2013) Using environmental DNA to estimate the distribution of an invasive fish species in ponds. PLoS ONE 8:e56584. doi:10.1371/journal.pone.0056584

Thomsen PF, Willerslev E (2015) Environmental DNA—an emerging tool in conservation for monitoring past and present biodiversity. Biol Conserv 183:4-18. doi:10.1016/j.biocon.2014.11.019

Thomsen PF, Elias S, Gilbert MTP et al (2009) Non-destructive sampling of ancient insect DNA. PLoS ONE 4:e5048. doi:10. 1371/journal.pone.0005048

Thomsen PF, Kielgast J, Iversen LL et al (2012a) Monitoring endangered freshwater biodiversity using environmental DNA. Mol Ecol 21:2565-2573. doi:10.1111/j.1365-294X.2011.05418.

Thomsen PF, Kielgast J, Iversen LL et al (2012b) Detection of a diverse marine fish fauna using environmental DNA from seawater samples. PLoS ONE 7:e41732. doi:10.1371/journal. pone.0041732

Toothman MH, Kester KM, Champagne J et al (2008) Characterization of human DNA in environmental samples. Forensic Sci Int 178:7-15. doi:10.1016/j.forsciint.2008.01.016

Toulza E, Blanc-Mathieu R, Gourbière S, Piganeau G (2012) Environmental and evolutionary genomics of microbial algae: power and challenges of metagenomics. Adv Bot Res 64:383-427

Tréguier A, Paillisson J, Dejean T et al (2014) Environmental DNA surveillance for invertebrate species: advantages and technical limitations to detect invasive crayfish Procambarus clarkii in freshwater ponds. J Appl Ecol 51:871-879. doi:10.1111/13652664.12262

Turner CR, Barnes MA, Xu CCY et al (2014a) Particle size distribution and optimal capture of aqueous macrobial eDNA. Methods Ecol Evol 5:676-684. doi:10.1111/2041-210X.12206

Turner CR, Miller DJ, Coyne KJ, Corush J (2014b) Improved methods for capture, extraction, and quantitative assay of environmental DNA from Asian bigheaded carp (Hypophthalmichthys spp.). PLoS ONE 9:e114329. doi:10.1371/journal. pone.0114329

Turner CR, Uy KL, Everhart RC (2015) Fish environmental DNA is more concentrated in aquatic sediments than surface water. Biol Conserv 183:93-102. doi:10.1016/j.biocon.2014.11.017

Valiere N, Taberlet P (2000) Urine collected in the field as a source of DNA for species and individual identification. Mol Ecol 9:2150-2152

Van Oorschot RAH, Ballantyne KN, Mitchell RJ (2010) Forensic trace DNA: a review. Investig Genet 1:14. doi:10.1186/20412223-1-14 
Vennemann M, Koppelkamm A (2010) mRNA profiling in forensic genetics I: possibilities and limitations. Forensic Sci Int 203:71-75. doi:10.1016/j.forsciint.2010.07.006

Vervoort MTW, Vonk JA, Mooijman PJW et al (2012) SSU ribosomal DNA-based monitoring of nematode assemblages reveals distinct seasonal fluctuations within evolutionary heterogeneous feeding guilds. PLoS ONE 7:e47555. doi:10.1371/ journal.-pone.0047555

Vuong N, Villemur R, Payment P et al (2013) Fecal source tracking in water using a mitochondrial DNA microarray. Water Res 47:16-30. doi:10.1016/j.watres.2012.09.011

Widmer F, Seidler RJ, Watrud LS (1996) Sensitive detection of transgenic plant marker gene persistence in soil microcosms. Mol Ecol 5:603-613. doi:10.1111/j.1365-294X.1996.tb00356.x

Widmer F, Seidler RJ, Donegan KK, Reed GL (1997) Quantification of transgenic plant marker gene persistence in the field. Mol Ecol 6:1-7

Wilcox TM, McKelvey KS, Young MK et al (2013) Robust detection of rare species using environmental DNA: the importance of primer specificity. PLoS ONE 8:e59520. doi:10.1371/journal. pone. 0059520

Wilcox TM, Schwartz MK, McKelvey KS et al (2014) A blocking primer increases specificity in environmental DNA detection of bull trout (Salvelinus confluentus). Conserv Genetics Resour 6:283-284. doi:10.1007/s12686-013-0113-4

Willerslev E, Hansen AJ, Binladen J et al (2003) Diverse plant and animal genetic records from holocene and pleistocene sediments. Science 300:791-795

Willerslev E, Cappellini E, Boomsma W et al (2007) Ancient biomolecules from deep ice cores reveal a forested southern Greenland. Science 317:111-114. doi:10.1126/science.1141758
Xu Z, Zhang F, Xu B et al (2009) Improving the sensitivity of negative controls in ancient DNA extractions. Electrophoresis 30:1282-1285. doi:10.1002/elps.200800473

Xu CCY, Yen IJ, Bowman D, Turner CR (2014) Spider web DNA: a new spin on noninvasive genetics of predator and prey. biorxiv. doi:10.1101/011775

Yang C, Wang X, Miller JA et al (2014) Using metabarcoding to ask if easily collected soil and leaf-litter samples can be used as a general biodiversity indicator. Ecol Indic 46:379-389. doi:10. 1016/j.ecolind.2014.06.028

Yankson KK, Steck TR (2009) Strategy for extracting DNA from clay soil and detecting a specific target sequence via selective enrichment and real-time (quantitative) PCR amplification. Appl Environ Microbiol 75:6017-6021. doi:10.1128/AEM.00211-09

Yoccoz NG (2012) The future of environmental DNA in ecology. Mol Ecol 21:2031-2038. doi:10.1111/j.1365-294X.2012.05505. $\mathrm{x}$

Yoccoz NG, Bråthen KA, Gielly L et al (2012) DNA from soil mirrors plant taxonomic and growth form diversity. Mol Ecol 21:3647-3655. doi:10.1111/j.1365-294X.2012.05545.x

Yooseph S, Andrews-Pfannkoch C, Tenney A et al (2013) A metagenomic framework for the study of airborne microbial communities. PLoS ONE. doi:10.1371/journal.pone.0081862

Zhu B (2006) Degradation of plasmid and plant DNA in water microcosms monitored by natural transformation and real-time polymerase chain reaction (PCR). Water Res 40:3231-3238. doi:10.1016/j.watres.2006.06.040

Zouros E, Ball AO, Saavedra C, Freeman KR (1994) Mitochondrial DNA inheritance. Nature 368:818. doi:10.1038/368818a0 